\title{
ANALISIS SENSITIVITAS ETIS CALON AKUNTAN MENGENAI KODE ETIK PROFESI AKUNTAN PUBLIK (Studi Pada Mahasiswa Akuntansi Universitas Jambi)
}

\author{
Oleh: \\ Amelia Astianof A. M \\ Enggar Diah Puspa Arum \\ (Dosen Program Studi Akuntansi Universitas Jambi)
}

\begin{abstract}
The purpose of this study is to analyze the difference of ethics sensitivity that contemplated by the profession ethics code of public accountants based on gender and levels of students in Universitas Jambi. The profession ethics of accountant in Indenesia are arranged in the Profession Ethics Code of Public Accountant. This study done to 214 students of Accounting Department in Universitas Jambi. Instrument used to analyze the data is Mann-Whitney U Test, with significance level 5\%. The results of this study wasn't show the difference on ethics sensitivity based on gender but there was a difference on ethics sensitivity based on levels of students.
\end{abstract}

Keywords: ethics sensitivity, gender, levels of students, profession ethics code of public accountants.

\section{Latar Belakang}

Etika akuntan telah menjadi isu yang sangat menarik. Di Amerika Serikat isu ini antara lain dipicu oleh terjadinya crash pasar modal tahun 1987 (Chua et al, 1994 dalam Ludigdo dan Machfoedz, 1999), sedangkan di Indonesia, isu ini berkembang seiring dengan terjadinya beberapa pelanggaran etika yang terjadi baik yang dilakukan oleh akuntan publik, akuntan intern, maupun akuntan pemerintah (Ludigdo dan Machfoedz, 1999).

Secara historis, akuntan merasa lebih etis dibanding dengan profesi-profesi lain, padahal isu pelanggaran etika yang dilakukan auditor semakin nyata terjadi (contoh yang paling fenomenal adalah kasus enron). Seharusnya hal ini tidak terjadi apabila setiap akuntan mempunyai pengetahuan, pemahaman, dan menerapkan etika secara memadai dalam pelaksanaan pekerjaan profesionalnya. Pekerjaan seorang profesional harus dikerjakan dengan sikap profesional pula, dengan sepenuhnya melandaskan pada standar moral dan etika tertentu. Akuntan akan mampu menghadapi berbagai tekanan yang dapat muncul dari dirinya sendiri ataupun pihak eksternal dengan sikap profesionalnya. Kemampuan seorang profesional untuk dapat mengerti dan peka terhadap persoalan etika juga sangat dipengaruhi oleh lingkungan dimana dia berada. Dalam hal ini, Sudibyo (1995) dalam Khomsiyah dan Indriantoro (1998) menyatakan bahwa dunia pendidikan akuntansi juga mempunyai pengaruh yang besar terhadap perilaku etika akuntan.

Dunia pendidikan tinggi mempunyai pengaruh yang besar terhadap perilaku etika akuntan. Dunia pendidikan yang baik akan mencetak mahasiswa menjadi calon akuntan yang mempunyai sikap profesional dan berlandaskan pada standar moral dan etika. Perguruan tinggi sebagai pemasok tenaga profesional ke dunia usaha dan bisnis mempunyai peran yang sangat strategis untuk mengantarkan dan mempersiapkan para mahasiswa menjadi calon-calon profesional yang mempunyai nilai- nilai dan sensitivitas etis yang baik. 
Integrasi etika ke dalam kurikulum akuntansi menjadi suatu tantangan kritis yang dihadapi oleh para pendidik di bidang akuntansi. AAA (1986) dan Andersen (1989) dalam Rustiana (2003) menyatakan bahwa pentingnya pendidikan etika dalam akuntansi telah diakui baik oleh praktisi maupun akademisi. Isu-isu tentang etika dalam pendidikan di bidang akuntansi juga telah direspon oleh banyak peneliti baik di dalam maupun di luar negeri.

Pendidikan akuntansi di Indonesia bertujuan menghasilkan lulusan yang beretika dan bermoral tinggi. Berbagai upaya dilakukan untuk memperkenalkan nilai-nilai profesi dan etika akuntan kepada mahasiswa. Dalam upaya pengembangan pendidikan akuntansi yang berlandaskan etika ini dibutuhkan adanya umpan balik (feedback) mengenai kondisi yang ada sekarang, yaitu apakah pendidikan akuntansi telah cukup membentuk nilai-nilai positif mahasiswa akuntansi (Yulianti dan Fitriany, 2005).

Terdapat beberapa faktor yang menimbulkan perbedaan persepsi tentang etika pada mahasiswa akuntansi (Rustiana, 2003). Pertama, berdasarkan perbedaan dalam keputusan etis berdasarkan gender. Dalam pendekatan sosialisasi gender, pria dan wanita memiliki perbedaan nilai dan perlakuan pada pekerjaan mereka. Pria berusaha mencari kesuksesan yang kompetitif dan agresif serta bila perlu akan melanggar aturan untuk mencapai kesuksesan tersebut, sedangkan wanita cenderung menekankan pada pelaksanaan tugas dengan baik dan lebih mementingkan harmonisasi dalam relasi (hubungan) kerja. Wanita lebih condong taat peraturan dalam menjaga hubungan tersebut sehingga wanita cenderung lebih etis dari pada pria. Kedua, tingkat atau jenjang semester. Stevens et al (1993) dalam Ludigdo dan Machfoedz (1999) mengemukakan bahwa mahasiswa semester akhir cenderung berorientasi etis dibanding mahasiswa semester awal. Yulianty dan Fitriany (2005) menemukan mahasiswa semester akhir telah memperoleh muatan mata kuliah yang berorientasi etis dibandingkan dengan mahasiswa yang masih di semester awal. Hal ini menunjukkan, bahwa muatan etika berperan dalam mata kuliah akuntansi.

\section{Rumusan Masalah}

Dari uraian latar belakang diatas maka rumusan masalah dalam penelitian ini adalah sebagai berikut:

1. Apakah terdapat perbedaan sensitivitas etis mengenai kode etik profesi akuntan publik pada mahasiswa pria dan mahasiswa wanita?

2. Apakah terdapat perbedaan sensitivitas etis mengenai kode etik profesi akuntan publik pada mahasiswa semester awal dan mahasiswa semester akhir?

\section{Kerangka Pemikiran}

Istilah etika jika dilihat dalam Kamus Besar Bahasa Indonesia (1999), memiliki tiga arti, yang salah satunya adalah nilai mengenai benar dan salah yang dianut suatu golongan atau masyarakat. Dari beberapa pengertian di atas dapat disimpulkan, bahwa etika merupakan seperangkat aturan/norma/pedoman yang mengatur perilaku manusia, baik yang harus dilakukan maupun yang harus ditinggalkan yang dianut oleh sekelompok/segolongan manusia/masyarakat/ profesi.

Menurut Keraf dan Imam (1997) dalam Martadi dan Suratna (2006), etika dapat dibagi menjadi dua, yaitu sebagai berikut:

1. Etika umum

Etika umum berkaitan dengan bagaimana manusia mengambil keputusan etis, teoriteori etika dan prinsip-prinsip moral dasar yang menjadi pegangan bagi manusia dalam bertindak, serta tolok ukur dalam menilai baik atau buruknya suatu tindakan. 
Etika umum dapat dianalogkan dengan ilmu pengetahuan, yang membahas mengenai pengertian umum dan teori-teori.

2. Etika khusus

Etika khusus adalah penerapan prinsip-prinsip moral dasar dalam bidang kehidupan yang khusus. Etika khusus dapat dibagi menjadi dua, yaitu:

a. Etika individual, menyangkut kewajiban dan sikap manusia terhadap dirinya sendiri.

b. Etika sosial, berkaitan dengan kewajiban, sikap dan pola perilaku manusia dengan manusia lainnya salah satu bagian dari etika sosial adalah etika profesi, termasuk etika profesi akuntan.

Riset di bidang akuntansi telah difokuskan pada kemampuan para akuntan dalam membuat keputusan etika dan berperilaku etis. Bagaimanapun, faktor yang penting dalam penilaian dan perilaku etis adalah kesadaran para individu bahwa mereka adalah agen moral. Kemampuan untuk menyadari adanya nilai-nilai etika atau moral dalam suatu keputusan inilah yang disebut sensitivitas etika.

Keputusan atau tindakan yang berkaitan dengan masalah moral harus mempunyai konsekuensi buat yang lain dan harus melibatkan pilihan atau kerelaan memilih dari sang pembuat keputusan. Definisi ini jadi memiliki pengertian yang luas, karena keputusan seringkali memiliki konsekuensi bagi pihak lain dan kerelaan untuk memilih hampir selalu merupakan pemberian, walaupun pilihan-pilihan itu seringkali memiliki resiko yang berat. Dalam beberapa hal, banyak keputusan dinilai sebagai keputusan moral hanya karena memiliki kandungan moral, padahal tidak demikian. Seperti yang dikatakan oleh Jones (1991:367) dalam Khomsiyah dan Indriantoro (1998), bahwa suatu keputusan dapat dinilai dari segi moral jika pada saat keputusan itu dibuat dengan memperhitungkan atau memasukkan nilai- nilai moral.

Sensitivitas etis merupakan kemampuan mahasiswa akuntansi untuk menyadari nilai-nilai etika atau moral dalam suatu keputusan etis (Rustiana, 2003). Sensitivitas etis dalam penelitian ini dikaitkan dengan kegiatan akademis mahasiswa selama dalam proses mendalami pengetahuan akuntasi serta direfleksikan dalam tindakan akademis yang berdampak pada perilaku etis setelah menjadi seorang akuntan. Ratdke (2000) dalam Rustiana (2003) mengemukakan bahwa sensitivitas etis merupakan gambaran atau proksi dari tindakan etis mahasiswa setelah lulus. Sensitivitas merupakan ciri-ciri tindakan yang mendeteksi kemungkinan lulusan dalam berperilaku etis. Apabila sebagai calon akuntan, mahasiswa telah berperilaku tidak etis maka kemungkinan setelah lulus akan berperilaku tidak etis. Hal ini perlu dideteksi sejak awal sebagai awal untuk mencegah perilaku tidak etis melalui cakupan atau muatan kurikulum etika dalam mata kuliah akuntansi, sehingga sebagai akuntan mampu bersaing dan dan bertindak secara profesional.

Keputusan etika menjadi rumit untuk dinilai terutama karena peraturan-peraturan yang ada tidak secara sempurna dapat menjadi sarana terwujudnya keputusan yang etis. Seringkali terjadi bahwa keputusan yang legal tidak selalu etis. Keadaan yang bias ini seringkali menjadi pemicu adanya masalah-masalah etika.

Mosse dalam Rianto (2008) mendefinisikan gender sebagai seperangkat peran yang dimainkan untuk menunjukkan kepada orang lain bahwa seseorang tersebut feminim atau maskulin. Penampilan, sikap, kepribadian, tanggung jawab keluarga adalah perilaku yang akan membentuk peran gender. Peran gender ini akan berubah seiring waktu dan berbeda antara satu kultur dengan kultur yang lainnya. Peran ini juga berpengaruh oleh kelas sosial, usia dan latar belakang etnis. Meningkatnya jumlah wanita yang memasuki dunia kerja dalam beberapa tahun terakhir mempengaruhi manajemen dalam pengelolaan diversitas yang berkaitan dengan gender. Isu tentang perbedaan 
gender dalam judgment etis relevan dalam bisnis, apalagi semakin banyaknya wanita masuk dalam bisnis dan menempati posisi-posisi penting dalam perusahaan sebagai para pembuat keputusan. Pada sebagian besar organisasi ternyata perbedaan gender masih mempengaruhi kesempatan (opportunity) dan kekuasaan (power) dalam suatu organisasi (Ratdke, 2000 dalam Rustiana, 2003).

Betz et al. (1989) dalam Rustiana (2003) menyatakan ada dua alternatif penjelasan mengenai perbedaan gender tentang perilaku tidak etis dalam bisnis. Pendekatan tersebut adalah pendekatan sosialisasi gender (gender sosialization approach) dan pendekatan struktural (structural approach). Pendekatan sosialisasi gender menyatakan bahwa pria dan wanita membawa perbedaan nilai dan perlakuan dalam pekerjaannya. Perbedaan ini disebabkan karena pria dan wanita mengembangkan bidang peminatan, keputusan dan praktik yang berbeda yang berhubungan dengan pekerjaannya. Pria dan wanita merespon secara berbeda tentang reward dan cost. Pria akan mencari kesuksesan kompetitif dan bila perlu melanggar aturan untuk mencapainya. Sedangkan wanita lebih menekankan pada melakukan tugasnya dengan baik dan lebih mementingkan harmonisasi dalam relasi pekerjaan. Wanita lebih condong taat pada peraturan dan kurang toleran dengan individu yang melanggar aturan.

Salah satu hal yang mempengaruhi seseorang berperilaku etis adalah lingkungan, diantaranya adalah lingkungan belajar (lingkungan kampus) yang bersifat hierarki. Mahasiswa yang telah lebih dulu atau yang lebih lama masa belajarnya yang biasa disebut dengan senior dan yang masih baru di suatu lingkungan kampus yang biasa disebut dengan junior.

Kata level berasal dari bahasa latin yaitu 'livel' yang berarti nilai dalam arti taksiran sesuatu, angka kepandaian, banyak sedikitnya. Sedangkan hierarkis dapat diartikan dengan susunan pemerintahan, organisasi yang dilakukan orang yang bertingkat pangkat dan kedudukannya. Dari pengertian tersebut dapat disimpulkan bahwa level hierarkis merupakan suatu kedudukan yang melambangkan suatu tingakatan atau angka.

Konsep level hierarkis pada penelitian ini lebih mengacu kepada tingkatan umur atau pengalaman seseorang yang lebih sering dikenal dengan senior dan junior. Kata senior dan junior berasal dari bahasa latin yang berarti angkatan atau golongan. Senior merupakan golongan yang lebih tua sedangkan junior merupakan golongan atau angkatan yang lebih muda.

Konvensi atau definisi tradisional kuno menyebutkan bahwa yang dimaksud dengan senior adalah orang yg lebih tua dalam segi usia dan dengan demikian dianggap banyak pengalaman dan lebih bijak. Namun bukan berarti yang lebih senior lebih bijak dalam melakukan berbagai hal. Intinya yang dihargai dari seorang senior adalah sikapnya yang bijak bukan kesenioran itu sendiri. Dengan kata lain, siapapun yang bersikap bijaksana, kreatif dan memiliki visi ke depan lebih maju, baik itu junior atau senior bahkan anak kecil sekalipun, seharusnya mendapat tanggapan yang sewajarnya di bidang dimana dia lebih mampu dari yang lebih tua angkatannya.

Penelitian etika berdasarkan gender pernah dilakukan oleh Sweeney yang menemukan bahwa akuntan wanita di KAP cenderung lebih etis dalam bisnis dibandingkan akuntan pria (Rustiana, 2003). Ada dua alternatif penjelas mengenai perbedaan gender tentang perilaku tidak etis dalam bisnis. Pendekatan tersebut adalah pendekatan sosialisasi gender (gender sosialization approach) dan pendekatan struktural (structural approach). Pendekatan sosialisasi gender menjelaskan bahwa pria dan wanita membawa perbedaan nilai dan perlakuan dalam pekerjaannya. Pria dan wanita merespon secara berbeda tentang reward dan cost. Pria berusaha mencari kesuksesan kompetisi dan bila perlu melanggar aturan untuk mencapai kesuksesan, hal ini menunjukkan kecenderungan tidak etis. Wanita lebih menekankan pada pelaksanaan tugas serta 
cenderung taat pada peraturan dan kurang toleran dengan individu yang melanggar aturan. Pada pendekatan struktural menjelaskan perbedaan perilaku etis disebabkan sosialisasi awal dan peran (Rustiana, 2003). Rueger dan King dalam Ludigdo dan Machfoedz (1999) meneliti pada mahasiswa yang mengambil mata kuliah bisnis. Hasil penelitian menunjukkan bahwa mahasiswa wanita mempunyai persepsi etis yang lebih baik dibandingkan mahasiswa pria. Hal konsisten dengan pendekatan sosialisasi gender. Ameen et al (1996) dalam Rustiana (2003) meneliti sensitivitas etis pada mahasiswa akuntansi di Southeast dan Southwest Amerika berdasarkan gender. Hasil penelitian menunjukkan mahasiswa akuntansi wanita lebih sensitif tentang isu-isu etis dan tidak toleran dibanding dengan mahasiswa akuntansi pria tentang perilaku tidak etis dalam aktivitas akademis. Jadi mahasiswa akuntansi wanita menunjukkan tingkat sensitivitas etis yang lebih tinggi dibandingkan dengan mahasiswa akuntansi pria. Penelitian Ratdke (2000) dalam Rustiana (2003) ditujukan untuk menyelidiki apakah gender berpengaruh terhadap keputusan sensitivitas etis pribadi atau bisnis pada akuntan publik dan akuntan internal. Hasil penelitian menunjukkan bahwa ada perbedaan respon sensitivitas etis antara akuntan pria dan wanita.

Penelitian lain mengenai masalah etika pernah dilakukan oleh Stevens et al (1993) dalam Ludigdo dan Mahfoedz (1999) yang melakukan perbandingan evaluasi etis dari staf pengajar (faculty) dan mahasiswa sekolah bisnis (School of business). Hasil penelitian menunjukkan bahwa staf pengajar lebih berorientasi etis dibandingkan mahasiswa. Glenn dan Van Loo (1993) dalam Ludigdo dan Mahfoedz (1999) melakukan penelitian untuk membandingkan keputusan dan sikap etis mahasiswa bisnis dengan keputusan dan sikap etis praktisi. Hasil analisis menunjukkan bahwa mahasiswa membuat keputusan yang kurang etis dibandingkan praktisi bisnis lainnya. Fischer dan Rosenzweig (1995) dalam Ludigdo dan Mahfoedz (1999) menguji tentang sikap mahasiswa dan sikap praktisi yang berkaitan dengan akseptabilitas etis atas manajemen laba (earnings). Hasil penelitian tersebut menunjukkan bahwa mahasiswa dan praktisi memiliki beberapa sensitivitas etis yang sama namun tidak merata. Yulianty dan Fitriany (2005) menemukan bahwa mahasiswa semester akhir cenderung berlaku etis dalam penyusunan laporan keuangan dibandingkan mahasiswa semester awal.

Hipotesis

$\mathrm{H}_{1}$ : Terdapat perbedaan sensitivitas etis mengenai kode etik profesi akuntan publik pada mahasiswa akuntansi pria dan wanita.

$\mathrm{H}_{2}$ : Terdapat perbedaan sensitivitas etis mengenai kode etik profesi akuntan publik pada mahasiswa semester awal dan akhir.

\section{Metode Penelitian}

Populasi dalam penelitian ini adalah seluruh mahasiswa jurusan akuntansi di Universitas Jambi angkatan 2006 sampai 2008 yang telah teregistrasi pada tahun akademik 2009/2010 sebanyak 480 orang mahasiswa. Metode pengambilan sampel dalam penelitian ini adalah metode probability dengan stratified proportional random sampling. Tujuannya adalah untuk memperoleh sampel yang respresentatif, pengambilan subjek dari setiap strata ditentukan seimbang atau sebanding dengan banyaknya subjek dalam masing-masing strata (Arikunto, 2006). Penentuan jumlah sampel minimum menggunakan rumus dari Isaac \& Michael sebagai berikut:

$$
n=\frac{\chi^{2} N P(1-P)}{d^{2}(N-1)+\chi^{2} P(1-P)}
$$


Keterangan:

$\begin{array}{ll}n & : \text { ukuran sampel } \\ N & : \text { ukuran populasi } \\ P & : \text { proporsi populasi } 0,5 \\ d & : \text { derajat ketelitian } 5 \% \\ \chi^{2} & : \text { nilai tabel chi-kuadrat }=3,84\end{array}$

Dari jumlah populasi tersebut dengan derajat ketelitian sebesar 5\%, maka dengan menggunakan rumus diatas diperoleh sampel sebesar:

$$
n=\frac{3,84 \cdot 480 \cdot 0,5(1-0,5)}{0,05^{2}(480-1)+3,84.0,5(1-0,5)}=214
$$

Untuk mengetahui jumlah sampel secara lebih rinci untuk setiap kelompok mahasiswa, maka digunakan rumus:

\section{Sampel pria:}

$$
n=\frac{\text { Jumlah populasi }}{\text { Jumlah populasi keseluruhan }} \times \text { Jumlah sampel keseluruhan }
$$

$n=\frac{189}{480} \times 214=84$

$n$ pria senior $=\frac{82}{189} \times 84=36$

$n$ pria junior $=\frac{107}{189} \times 84=48$

\section{Sampel wanita:}

$$
\begin{aligned}
& n=\frac{291}{480} \times 214=130 \\
& n \text { wanita senior }=\frac{121}{291} \times 130=54 \\
& n \text { wanita junior }=\frac{170}{291} \times 130=76
\end{aligned}
$$

Kuesioner yang akan digunakan telah melalui tahap analisis data pada penelitian sebelumnya, yang meliputi pengujian validitas dan reliabilitas data. Menurut Sekaran (2006) validitas menunjukkan ketepatan dan kecermatan alat ukur dalam melakukan dalam melakukan fungsi ukurnya. Sebuah item dinyatakan valid/ sahih apabila $r$-hitung lebih besar dari $r$-tabel (Priyatno, 2008). Uji validitas dilakukan untuk mengetahui apakah suatu instrumen alat ukur telah menjalankan fungsi ukurnya. Pada penelitian ini validitas yang di uji adalah validitas konstruk (construct validity) dengan mengkorelasikan skor masing- masing butir dengan skor total. Skor total sendiri adalah skor yang didapat dari penjumlahan skor butir untuk instrumen tersebut. Uji validitas dalam penelitian ini menggunakan korelasi product moment pearson. Instrumen dikatakan valid jika $r$-hitung $\geq$ r-tabel. Uji validitas data dibantu dengan program SPSS for Windows.

Untuk pengujian reliabilitas menggunakan cronbach alpha untuk menunjukkan sejauh mana suatu alat dapat dipercaya untuk mengukur suatu obyek, koefisien alpha yang semakin mendekati 1 berarti butir-butir pertanyaan dalam koefisien semakin reliabel. Sebuah faktor dinyatakan reliabel jika koefisien Alpha lebih besar dari 0,8 (Sekaran, 2003:41). 
Pengujian reliabilitas adalah berkaitan dengan masalah adanya kepercayaan terhadap instrumen. Suatu instrumen dapat memiliki tingkat kepercayaan yang tinggi (konsisten) jika hasil dari pengujian instrumen tersebut menunjukkan hasil yang tetap. Dengan demikian, masalah reliabilitas instrumen berhubungan dengan masalah ketepatan hasil. Uji reliabilitas dilakukan untuk mengetahui tingkat kestabilan suatu alat ukur. Pada penelitian ini, uji reliabilitas dilakukan dengan menggunakan Cronbach Alpha yang terdapat pada program komputer SPSS for Windows.

Di dalam analisis data penelitian digunakan metode statistika. Seluruh perhitungan statistik dilakukan dengan menggunakan bantuan program aplikasi SPSS for Windows dengan analisis Mann Whitney U-Test. Analisis U-test digunakan untuk menguji hipotesis komparatif dua sampel independen bila datanya berbentuk ordinal. Bila data masih berbentuk interval, sebenarnya dapat menggunakan t-test untuk pengujiannya, tetapi bila asumsi t-test tidak dipenuhi (misal data harus normal), maka test ini dapat digunakan (Sugiyono, 2008).

Langkah pengujian hipotesis dalam penelitian ini adalah sebagai berikut:

1. Sensitivitas etis mahasiswa terhadap kode etik akuntan publik, yang terdiri dari 16 pernyataan yang dilihat dari 2 bagian, yaitu prinsip dasar etika profesi, dan aturan etika profesi.

2. Sampel yang digunakan adalah mahasiswa yang dibagi dalam dua kelompok yaitu mahasiswa pria dan mahasiswa wanita, dan mahasiswa tingkat akhir dan mahasiswa tingkat awal.

3. Masing-masing kelompok akan dihitung meannya, kemudian mean tersebut akan diuji dengan statistik Mann Whitney U-Test.

Hipotesis untuk mengetahui apakah terdapat perbedaan sensitivitas etis atau tidak, adalah:

$\mathrm{H}_{01}$ : Tidak terdapat perbedaan sensitivitas etis antara mahasiswa akuntansi pria dan mahasiswa akuntansi wanita

$\mathrm{H}_{\mathrm{a} 1}$ : Terdapat perbedaan sensitivitas etis antara mahasiswa akuntansi pria dan mahasiswa akuntansi wanita

$\mathrm{H}_{02}$ : Tidak terdapat perbedaan sensitivitas etis antara mahasiswa akuntansi tingkat akhir dan mahasiswa akuntansi tingkat awal

$\mathrm{H}_{\mathrm{a} 2}$ : Terdapat perbedaan sensitivitas etis antara mahasiswa akuntansi tingkat akhir dan mahasiswa akuntansi tingkat awal

Hasil uji Mann Whitney U-Test dapat diambil suatu keputusan. Dasar pengambilan keputusannya adalah jika probabilitas lebih besar dari 0,05 ( $\mathrm{p}$ value $>0,05$ ) maka $\mathrm{H}_{\mathrm{a}}$ ditolak, artinya tidak ada perbedaan antara kelompok sampel. Sebaliknya jika probabilitas lebih kecil dari 0,05 ( $\mathrm{p}$ value $<0,05)$ maka $\mathrm{H}_{\mathrm{a}}$ diterima, artinya terdapat perbedaan antara kelompok sampel.

Variabel Penelitian (operasional variabel) adalah suatu atribut atau sifat atau nilai dari orang, objek atau kegiatan yang mempunyai variasi tertentu yang ditetapkan oleh peneliti untuk dipelajari dan ditarik kesimpulannya (sugiyono, 2005).

Adapun variabel dalam penelitian ini adalah sensitivitas etis mahasiswa tentang kode etik profesi akuntan publik. Sensitivitas etis adalah kemampuan untuk menyadari nilai-nilai etika atau moral dalam suatu keputusan (Khomsiah dan Indriantoro, 1998). Sensitivitas etis mahasiswa sebagai calon akuntan mengenai kode etik profesi akuntan publik dapat dilihat dari dua dimensi, yaitu prinsip dasar etika profesi; dan aturan etika profesi.

a. Prinsip dasar etika profesi (pernyataan 1 - 6), meliputi prinsip integritas; prinsip objektivitas; prinsip kompetensi serta sikap kecermatan dan kehati-hatian profesional; prinsip kerahasiaan; dan prinsip perilaku profesional. 
b. Aturan etika profesi (pernyataan 7 - 16), meliputi ancaman dan pencegahan; penunjukan praktisi, KAP, atau jaringan KAP; benturan kepentingan; pendapat kedua; imbalan jasa professional dan bentuk remunerasi lainnya; pemasaran jasa profesional; penerimaan hadiah atau bentuk keramah-tamahan lainnya; penyimpanan aset milik klien; objektivitas semua jasa profesional; dan independensi dalam perikatan assurance.

Definisi operasional variabel dalam penelitian ini dapat digambarkan sebagai berikut:

Tabel 1. Definisi Operasional Variabel

\begin{tabular}{|c|c|c|c|}
\hline $\begin{array}{l}\text { Variabel } \\
\text { Penelitian }\end{array}$ & $\begin{array}{c}\text { Sub } \\
\text { Variabel }\end{array}$ & Indikator & $\begin{array}{l}\text { Skala } \\
\text { Ukur }\end{array}$ \\
\hline \multirow[t]{2}{*}{$\begin{array}{l}\text { Sensitivitas etis } \\
\text { calon akuntan } \\
\text { (mahasiswa) } \\
\text { tentang kode } \\
\text { etik profesi } \\
\text { akuntan publik }\end{array}$} & $\begin{array}{l}\text { 1. Prinsip } \\
\text { dasar } \\
\text { etika } \\
\text { profesi }\end{array}$ & $\begin{array}{ll}\text { a. } & \text { prinsip integritas } \\
\text { b. prinsip objektivitas } \\
\text { c. prinsip kompetensi serta sikap } \\
\text { kecermatan dan kehati-hatian } \\
\text { d. profesional } \\
\text { e. prinsip kerahasiaan } \\
\text { e. }\end{array}$ & $\begin{array}{c}\text { Skala } \\
\text { Ordinal }\end{array}$ \\
\hline & $\begin{array}{l}\text { 2. Aturan } \\
\text { etika } \\
\text { profesi }\end{array}$ & $\begin{array}{l}\text { a. ancaman dan pencegahan } \\
\text { b. penunjukan praktisi, KAP, atau } \\
\text { jaringan KAP } \\
\text { c. benturan kepentingan } \\
\text { d. pendapat kedua } \\
\text { e. imbalan jasa professional dan bentuk } \\
\text { remunerasi lainnya } \\
\text { f. pemasaran jasa profesional } \\
\text { g. penerimaan hadiah atau bentuk } \\
\text { keramah-tamahan lainnya } \\
\text { h. penyimpanan aset milik klien } \\
\text { i. objektivitas-semua jasa profesional } \\
\text { j. independensi dalam perikatan } \\
\text { assurance }\end{array}$ & $\begin{array}{c}\text { Skala } \\
\text { Ordinal }\end{array}$ \\
\hline
\end{tabular}

\section{Hasil dan Pembahasan}

Kuesioner yang didistribusikan sebanyak 214 buah. Kuesioner ini disebarkan kepada sebagian mahasiswa akuntansi Universitas Jambi yang termasuk semester awal dan akhir. Kuesioner yang kembali sebesar 214 kuesioner karena disebarkan secara langsung pada responden. Tingkat pengembalian kuesioner disajikan dalam tabel 2 berikut ini:

Tabel 2. Jumlah Sampel dan Tingkat Pengembalian

\begin{tabular}{|l|c|}
\hline \multicolumn{1}{|c|}{ Keterangan } & Jumlah \\
\hline Kuesioner yang disebar & 214 \\
\hline Kuesioner yang kembali & 214 \\
\hline Response rate & $100 \%$ \\
\hline Kuesioner yang tidak kembali & 0 \\
\hline Total kuesioner yang dianalisis & 214 \\
\hline
\end{tabular}

Sumber: Data yang diolah

Data responden berdasarkan jenis kelamin dapat dilihat dalam tabel 3 yang dikategorikan menjadi 2 kelompok, yaitu mahasiswa pria dan mahasiswa wanita. 
Tabel 3. Karakteristik Responden Berdasarkan Jenis Kelamin

\begin{tabular}{|l|c|c|c|}
\hline \multicolumn{1}{|c|}{ Mahasiswa } & Jumlah & Persentase & Rata-rata Sensitivitas Etis \\
\hline Pria & 84 & $39,25 \%$ & 4,02 \\
\hline Wanita & 130 & $60,75 \%$ & 4,10 \\
\hline Total & 214 & $100 \%$ & \\
\hline
\end{tabular}

Sumber: Data yang diolah

Dari tabel 3 dapat diidentifikasi bahwa responden dalam penelitian ini berjumlah 214 mahasiswa yang terdiri dari pria dan wanita. Responden yang berjenis kelamin wanita berjumlah 130 orang $(60,75 \%)$ dan responden yang berjenis kelamin pria berjumlah 84 orang $(39,25 \%)$. Berdasarkan nilai rata-rata dapat diketahui bahwa mahasiswa pria memiliki sensitivitas etis sebesar 4,02 yang lebih rendah dibandingkan mahasiswa wanita yang memiliki sensitivitas etis sebesar 4,10.

Data responden berdasarkan tingkatan semester dapat dilihat dalam tabel 4 yang dikategorikan menjadi 2 kelompok, yaitu mahasiswa tingkat akhir dan mahasiswa tingkat awal.

Tabel 4. Karakteristik Responden Berdasarkan Tingkat Semester

\begin{tabular}{|l|c|c|c|}
\hline \multicolumn{1}{|c|}{ Mahasiswa } & Jumlah & Persentase & $\begin{array}{c}\text { Rata-rata } \\
\text { Sensitivitas Etis }\end{array}$ \\
\hline Tingkat Akhir/ Senior & 90 & $42,06 \%$ & 4,13 \\
\hline Tingkat Awal/ Junior & 124 & $57,94 \%$ & 4,03 \\
\hline Total & 214 & $100 \%$ & \\
\hline
\end{tabular}

Sumber: Data yang diolah

Dari tabel 4 dapat diidentifikasi bahwa responden dalam penelitian ini mahasiswa semester awal berjumlah 124 orang atau sebesar 57,94\%, dan responden mahasiswa semester akhir berjumlah 90 orang $(42,06 \%)$. Berdasarkan nilai rata-rata dapat diketahui bahwa mahasiswa semester awal memiliki sensitivitas etis sebesar 4,03 yang lebih rendah dibandingkan mahasiswa semester akhir yang memiliki sensitivitas etis sebesar 4,13.

Uji validitas dalam penelitian ini menggunakan korelasi product moment pearson dengan alat bantu statistik SPSS for Windows versi 12. Hasil uji validitas dan reliabilitas sebagai berikut:

Tabel 5. Uji Validitas Sensitivitas Etis

\begin{tabular}{|c|c|c|c|}
\hline Item Variabel & r-hitung & r-tabel & Keterangan \\
\hline Item1 & 0,409 & 0,134 & Valid \\
\hline Item2 & 0,545 & 0,134 & Valid \\
\hline Item3 & 0,489 & 0,134 & Valid \\
\hline Item4 & 0,509 & 0,134 & Valid \\
\hline Item5 & 0,558 & 0,134 & Valid \\
\hline Item6 & 0,553 & 0,134 & Valid \\
\hline Item7 & 0,598 & 0,134 & Valid \\
\hline Item8 & 0,586 & 0,134 & Valid \\
\hline Item9 & 0,591 & 0,134 & Valid \\
\hline Item10 & 0,550 & 0,134 & Valid \\
\hline Item11 & 0,482 & 0,134 & Valid \\
\hline Item12 & 0,439 & 0,134 & Valid \\
\hline Item13 & 0,494 & 0,134 & Valid \\
\hline Item14 & 0,548 & 0,134 & Valid \\
\hline Item15 & 0,496 & 0,134 & Valid \\
\hline Item16 & 0,459 & 0,134 & Valid \\
\hline
\end{tabular}

Sumber: Data yang diolah 
Berdasarkan hasil uji validitas menggunakan analisis korelasi product moment pearson diketahui bahwa $r$-hitung untuk variabel sensitivitas etis terhadap kode etik profesi akuntan publik lebih besar dari $r$-tabel. Sebuah item dinyatakan valid/sahih apabila $r$-hitung lebih besar dari $r$-tabel (Priyatno,2008). Dengan demikian semua item dalam penelitian ini valid/sahih.

Reliabilitas menunjukkan konsistensi alat pengukur dalam mengukur gejala yang sama. Menurut Sekaran (2006) sebuah variabel dikatakan reliabel apabila alpha lebih besar 0,8 . Tabel 6 berikut akan menunjukkan hasil dari uji reliabilitas yang telah dilakukan:

Tabel 6. Uji Reliabilitas Sensitivitas Etis

\begin{tabular}{|l|c|}
\hline \multicolumn{1}{|c|}{ Variabel } & Alpha \\
\hline $\begin{array}{l}\text { Sensitivitas Etis terhadap Kode Etik Profesi } \\
\text { Akuntan Publik }\end{array}$ & 0,808 \\
\hline
\end{tabular}

Sumber: Data yang diolah

Berdasarkan hasil uji reliabilitas menggunakan cronbach alpha diketahui bahwa dimensi sensitivitas etis terhadap kode etik profesi akuntan publik memiliki alpha sebesar 0,808 . Dengan demikian semua variabel dalam penelitian ini reliabel.

Penelitian ini bertujuan mengetahui perbedaan sensitivitas etis mahasiswa akuntansi terhadap kode etik profesi akuntan publik berdasarkan gender. Berikut ini hasil analisis perbedaan sensitivitas etis pada mahasiswa akuntansi terhadap kode etik profesi akuntan publik berdasarkan gender menggunakan analisis Mann Whitney U-Test disajikan dalam tabel 7 berikut ini:

Tabel 7. Hasil Uji Mann Whitney U-Test pada Mahasiswa Akuntansi Pria dan Mahasiswa Akuntansi Wanita

\begin{tabular}{|l|c|c|c|}
\hline $\begin{array}{l}\text { Karakteristik } \\
\text { Mahasiswa }\end{array}$ & $\begin{array}{c}\text { Rata-rata } \\
\text { Sensitivitas Etis }\end{array}$ & p value & Keterangan \\
\hline Pria & 4,02 & 0,175 & $\mathrm{H}_{1}$ ditolak \\
\hline Wanita & 4,10 & 0 & \\
\hline
\end{tabular}

Sumber: Data yang diolah

Berdasarkan tabel 7 di atas dapat diketahui nilai probabilitas sebesar 0,175, atau probabilitas besar dari $0,05(0,175>0,05)$, sehingga Ho diterima dan Ha ditolak. Dengan demikian hipotesis yang menyatakan terdapat perbedaan sensitivitas etis pada mahasiswa akuntansi pria dan mahasiswa akuntansi wanita ditolak.

Pengujian untuk setiap pernyataan dalam kuesioner ditunjukkan pada tabel 8 yang menggambarkan rata-rata penilaian mahasiswa akuntansi pria dan mahasiswa akuntansi wanita. Dari tabel 8 ditunjukkan terdapat perbedaan yang yang tidak signifikan antara mahasiswa pria dan mahasiswa wanita pada pernyataan nomor 7 , dimana $\mathrm{H}_{0}$ ditolak karena $p$ value $<0,05$. Dalam hal ini sensitivitas etis mahasiswa wanita terhadap ancaman dan pencegahan aturan etika profesi akuntan publik lebih positif (baik) daripada mahasiswa pria.

Tabel 8. Rata-rata Penilaian Mahasiswa Akuntansi Pria dan Mahasiswa Akuntansi Wanita

\begin{tabular}{|l|l|l|l|l|l|}
\hline \multirow{2}{*}{ Pernyataan } & \multicolumn{2}{|l|}{ Pria } & Wanita & \multirow{2}{*}{ p value } \\
\cline { 2 - 5 } & Mean & Std Dev & Mean & Std Dev & \\
\hline Item1 & 4,63 & 0,576 & 4,69 & 0,496 & 0,557 \\
\hline Item2 & 4,39 & 0,659 & 4,50 & 0,600 & 0,260 \\
\hline
\end{tabular}




\begin{tabular}{|l|l|l|l|l|l|}
\hline Item3 & 4,43 & 0,626 & 4,56 & 0,584 & 0,112 \\
\hline Item4 & 4,37 & 0,617 & 4,32 & 0,718 & 0,840 \\
\hline Item5 & 3,99 & 0,963 & 4,22 & 0,828 & 0,080 \\
\hline Item6 & 4,38 & 0.693 & 4,44 & 0,635 & 0,630 \\
\hline Item7 & $\mathbf{4 , 0 7}$ & $\mathbf{0 , 7 2 5}$ & $\mathbf{4 , 2 8}$ & $\mathbf{0 , 6 2 3}$ & $\mathbf{0 , 0 4 5}$ \\
\hline Item8 & 3,69 & 0,905 & 3,84 & 0,786 & 0,374 \\
\hline Item9 & 3,92 & 0,764 & 4,03 & 0,704 & 0,283 \\
\hline Item10 & 3,94 & 0,782 & 3,91 & 0,752 & 0,559 \\
\hline Item11 & 3,81 & 0,857 & 3,69 & 0,979 & 0,536 \\
\hline Item12 & 3,92 & 0,908 & 3,95 & 0,791 & 0,917 \\
\hline Item13 & 3,26 & 1,131 & 3,44 & 1,064 & 0,274 \\
\hline Item14 & 3,96 & 0,813 & 4,13 & 0,791 & 0,097 \\
\hline Item15 & 3,26 & 1,204 & 3,45 & 1,155 & 0,243 \\
\hline Item16 & 4,27 & 0,812 & 4,15 & 0,706 & 0,100 \\
\hline
\end{tabular}

Sumber: Data yang diolah

Berdasarkan tabel tersebut tampak terdapat perbedaan antara mahasiswa pria dengan mahasiswa wanita pada pernyataan nomor 7 . Nilai p value $<0,05$, maka $\mathrm{H}_{0}$ ditolak. Dari pernyataan nomor 7 , nilai rata-rata dapat diketahui bahwa mahasiswa pria memiliki sensitivitas etis sebesar 4,07 yang lebih rendah dibandingkan mahasiswa wanita yang memiliki sensitivitas etis sebesar 4,28. Hal ini menunjukkan bahwa mahasiswa wanita cendrung lebih etis dibanding mahasiswa pria, tentang sikap calon akuntan terhadap item "selalu waspada terhadap situasi dan ancaman yang mungkin timbul dalam melaksanakan suatu perikatan audit".

Berikut ini hasil analisis perbedaan sensitivitas etis pada mahasiswa akuntansi terhadap kode etik profesi akuntan publik berdasarkan tingkat semester menggunakan analisis Mann Whitney U-Test disajikan dalam tabel 9 di bawah ini:

Tabel 9. Hasil Uji Mann Whitney U-Test pada Mahasiswa Akuntansi Tingkat Akhir dan Mahasiswa Akuntansi Tingkat Awal

\begin{tabular}{|c|l|l|l|}
\hline $\begin{array}{c}\text { Karakteristik } \\
\text { Mahasiswa }\end{array}$ & $\begin{array}{c}\text { Rata-rata } \\
\text { Sensitivitas Etis }\end{array}$ & \multicolumn{1}{|c|}{$p$ value } & Keterangan \\
\hline Tingkat Akhir & 4,13 & 0,025 & $\mathrm{H}_{2}$ diterima \\
\hline Tingkat Awal & 4,03 & & \\
\hline
\end{tabular}

Sumber: Data yang diolah

Berdasarkan tabel 9 di atas dapat diketahui nilai probabilitas sebesar 0,025 , atau probabilitas kecil dari $0,05(0,025<0,05)$, sehingga Ho ditolak dan Ha diterima. Dengan demikian hipotesis yang menyatakan terdapat perbedaan sensitivitas etis pada mahasiswa akuntansi tingkat akhir dan mahasiswa akuntansi tingkat awal diterima.

Pengujian untuk setiap pernyataan dalam kuesioner ditunjukkan pada tabel 10 yang menggambarkan rata-rata penilaian mahasiswa akuntansi tingkat akhir dan mahasiswa akuntansi tingkat awal.

Tabel 10. Rata-Rata Penilaian Mahasiswa Akuntansi Tingkat Akhir dan Mahasiswa Akuntansi Tingkat Awal

\begin{tabular}{|l|l|l|l|l|l|}
\hline \multirow{2}{*}{ Pernyataan } & \multicolumn{2}{|l|}{ Tingkat Akhir } & \multicolumn{2}{l|}{ Tingkat Awal } & \multirow{2}{*}{ v value } \\
\cline { 2 - 5 } & Mean & Std Dev & Mean & Std Dev & \\
\hline Item1 & 4.79 & 0.410 & 4.58 & 0.586 & 0,008 \\
\hline Item2 & 4.59 & 0.538 & 4.36 & 0.667 & 0,014 \\
\hline Item3 & 4.62 & 0.552 & 4.43 & 0.627 & 0,019 \\
\hline
\end{tabular}




\begin{tabular}{|l|l|l|l|l|l|}
\hline Item4 & 4.33 & 0.670 & 4.35 & 0.687 & 0,845 \\
\hline Item5 & 4.14 & 0.978 & 4.12 & 0.822 & 0,477 \\
\hline Item6 & 4.42 & 0.687 & 4.41 & 0.638 & 0,751 \\
\hline Item7 & 4.23 & 0.671 & 4.17 & 0.671 & 0,448 \\
\hline Item8 & 3.88 & 0.885 & 3.71 & 0.794 & 0,078 \\
\hline Item9 & 3.99 & 0.772 & 3.98 & 0.698 & 0,735 \\
\hline Item10 & 3.93 & 0.818 & 3.91 & 0.721 & 0,604 \\
\hline Item11 & 3.71 & 0.997 & 3.76 & 0.887 & 0,730 \\
\hline Item12 & 3.88 & 0.832 & 3.98 & 0.841 & 0,318 \\
\hline Item13 & 3.40 & 1.130 & 3.35 & 1.067 & 0,582 \\
\hline Item14 & 4.16 & 0.847 & 4.00 & 0.765 & 0,062 \\
\hline Item15 & $\mathbf{3 . 5 6}$ & $\mathbf{1 . 2 0 0}$ & $\mathbf{3 . 2 4}$ & $\mathbf{1 . 1 4 3}$ & $\mathbf{0 , 0 4 3}$ \\
\hline Item16 & $\mathbf{4 . 3 7}$ & $\mathbf{0 . 6 9 4}$ & $\mathbf{4 . 0 7}$ & $\mathbf{0 . 7 6 7}$ & $\mathbf{0 , 0 0 4}$ \\
\hline
\end{tabular}

Sumber: Data yang diolah

Berdasarkan tabel tersebut tampak terdapat perbedaan antara mahasiswa tingkat akhir dengan mahasiswa tingkat awal pada pernyataan nomor $1,2,3,15$, dan 16 . Nilai $p$ value $<0,05$, maka $\mathrm{H}_{0}$ ditolak. Dari pernyataan nomor $1,2,3,15$, dan 16 nilai rata-rata dapat diketahui bahwa mahasiswa tingkat awal memiliki sensitivitas etis yang lebih rendah dibandingkan mahasiswa tingkat akhir. Hal ini menunjukkan bahwa mahasiswa tingkat akhir cendrung lebih etis dibanding mahasiswa tingkat awal, tentang sikap calon akuntan terhadap item "bersikap tegas dan jujur dalam melaksanakan pekerjaan audit, bersikap objektif dalam setiap hubungan bisnis dengan klien, dalam memberikan jasa audit auditor menggunakan kemahiran profesionalnya sesuai dengan standar profesi dan kode etik profesi yang berlaku, hubungan kekeluargaan dengan klien dapat mengurangi objektivitas auditor dalam memberikan jasa profesionalnya, bersikap independen terhadap klien selama melaksanakan perikatan assurance".

\section{Hasil dan Pembahasan}

Berdasarkan analisis Mann Whitney U-Test diketahui bahwa tidak terdapat perbedaan sensitivitas etis pada mahasiswa akuntansi pria dan mahasiswa akuntansi wanita secara signifikan. Berdasarkan rata-rata (means) diketahui bahwa sensitivitas etis mahasiswa akuntansi pria sebesar 4,02 lebih rendah dibandingkan mahasiswa akuntansi wanita sebesar 4,10. Hasil penelitian ini sejalan dengan penelitian Martadi dan Suratna (2006) yang menemukan tidak terdapat perbedaan persepsi berdasarkan gender antara mahasiswa akuntansi pria dan mahasiswa akuntansi wanita mengenai etika bisnis dan etika profesi, dibandingkan penelitian Rustiana (2003) ternyata tidak sejalan dengan penelitian ini dimana penelitian tersebut menyatakan terdapat perbedaan sensitivitas etis antara mahasiswa akuntansi pria dan mahasiswa akuntansi wanita dalam aktivitas akademis yang dihadapi.

Berdasarkan analisis selanjutnya dengan menggunakan analisis Mann Whitney U-Test diketahui bahwa terdapat perbedaan sensitivitas etis pada mahasiswa akuntansi semester awal dan mahasiswa akuntansi semester akhir. Hal yang mendasari pemikiran ini adalah mahasiswa yang memperoleh pengetahuan mengenai kode etik profesi akuntan publik dalam mata kuliah auditing cenderung mengetahui penilaian etis suatu keputusan, berbeda dengan mahasiswa semester awal yang belum memperoleh cakupan pengetahuan mengenai kode etik profesi akuntan publik di mata kuliah semester awal sehingga cenderung mengabaikan etika dalam pengambilan keputusan. Berdasarkan rata-rata (means) diketahui bahwa sensitivitas etis mahasiswa akuntansi semester awal sebesar 4,03 lebih rendah dibandingkan mahasiswa akuntansi semester akhir sebesar 4,13. Beberapa temuan yang menemukan terdapat perbedaan sensitivitas etis berdasarkan semester yaitu Yulianty dan Fitriany (2005) menemukan bahwa mahasiswa semester 
akhir cenderung berlaku etis dalam penyusunan laporan keuangan dibandingkan mahasiswa semester akhir. Namun hasil tidak konsisten dengan penelitian Ludigdo dan Machfoedz (1999) yang menemukan tidak ada perbedaan yang signifikan antara mahasiswa semester awal dan akhir, meskipun hasil tersebut menunjukkan bahwa mahasiswa akhir memiliki sensitivitas etis yang lebih baik di bandingkan mahasiswa awal. Hal yang mendasari hasil tersebut adalah kesamaan cakupan etika pada mata kuliah semester awal dan akhir sehingga tidak berbeda secara signifikan.

\section{Simpulan}

1. Berdasarkan hasil uji Mann Whitney U-Test dapat disimpulkan bahwa tidak terdapat perbedaan sensitivitas etis antara mahasiswa akuntansi pria dan mahasiswa akuntansi wanita mengenai kode etik profesi akuntan publik. Jika dilihat dari rata-rata (mean) penilaian masing-masing item kuesioner, perbedaan hanya terdapat pada pernyataan bahwa auditor harus selalu waspada terhadap situasi dan ancaman yang mungkin timbul dalam melaksanakan suatu perikatan audit. Dari perbedaan yang ada, sensitivitas etis mahasiswa akuntansi wanita lebih baik daripada sensitivitas etis mahasiswa akuntansi pria.

2. Berdasarkan hasil uji Mann Whitney U-Test dapat disimpulkan bahwa terdapat perbedaan sensitivitas etis antara mahasiswa akuntansi semester awal dan mahasiswa akuntansi semester akhir mengenai kode etik profesi akuntan publik. Jika dilihat dari rata-rata (mean) penilaian masing-masing item kuesioner, perbedaan terdapat pada pernyataan bahwa auditor harus bersikap tegas dan jujur dalam melaksanakan pekerjaan audit, auditor harus bersikap objektif dalam setiap hubungan bisnis dengan klien, dalam memberikan jasa audit, auditor menggunakan kemahiran profesionalnya sesuai dengan standar profesi dan kode etik profesi yang berlaku, hubungan kekeluargaan dengan klien dapat mengurangi objektivitas auditor dalam memberikan jasa profesionalnya, auditor harus bersikap independen terhadap klien selama melaksanakan perikatan assurance. Dari perbedaan yang ada, sensitivitas etis mahasiswa akuntansi semester akhir lebih baik daripada sensitivitas etis mahasiswa akuntansi semester.

\section{Keterbatasan Penelitian}

Hasil analisis dari penelitian ini terdapat adanya sejumlah keterbatasan yang diharapkan dapat diperbaiki untuk penelitian selanjutnya. Keterbatasan-keterbatasan dalam penelitian ini antara lain :

1. Persepsi responden tergantung pada pemahaman butir pertanyaan yang tercantum dalam kuesioner sehingga kemungkinan terjadi perbedaan persepsi responden dengan pengukuran yang bersifat self reported sehingga kemungkinan terjadi liniency bias.

2. Penelitian ini hanya dilakukan survei melalui kuesioner tanpa dilengkapi dengan metode pengumpulan data lainnya untuk keakuratan data yang diteliti seperti wawancara. Peneliti memberikan saran agar metode pengumpulan data selanjutnya dapat dilengkapi dengan metode lainnya seperti wawancara agar data yang dikumpulkan lebih akurat dan menghindari perbedaan persepsi responden dengan pengukuran.

3. Survey dalam penelitian ini dilakukan pada satu universitas sehingga hasil dari penelitian ini bisa saja "unik" dalam artian hanya terjadi dalam universitas tempat dilakukannya survey saja. 
Saran

Adanya keterbatasan penelitian ini yang diungkapkan di atas, peneliti berharap hasil penelitian ini dapat menambah wacana dalam pengembangan literatur akuntansi keperilakuan. Selain itu, diharapkan juga dapat bermanfaat bagi:

1. Pengembangan etika pada mahasiswa akuntansi selaku calon akuntan, serta sebagai tambahan litelatur pengetahuan di bidang akuntansi keperilakuan.

2. Pengembangan kurikulum bidang akuntansi dengan mempertimbangkan faktor perilaku etis calon akuntan sehingga mampu bersaing di dunia praktisi.

3. Pentingnya cakupan etika dalam mata kuliah akuntansi dibuktikan dengan adanya perbedaan sensitivitas etis antara mahasiswa akuntansi semester awal yang belum memperoleh cakupan etika dalam mata kuliahnya dibandingkan mahasiswa semester akhir yang telah mengambil mata kuliah bermuatan etika sehingga lebih etis dibandingkan juniornya.

4. Penelitian selanjutnya dapat juga mengembangkan perspektif yang diteliti lebih luas lagi misalnya, perbandingan mahasiswa dengan akuntan pendidik yang merupakan fasilitator dalam mentransfer ilmu mengenai kode etik profesi akuntan publik.

\section{Daftar Pustaka}

Arikunto, Suharsimi. 2006. Prosedur Penelitian Suatu Pendekatan Praktik. Jakarta: Rineka Cipta.

Departemen Pendidikan dan Kebudayaan RI. 1999. Kamus Besar Bahasa Indonesia, Jakarta: Balai Pustaka.

Fakih, Mansour. 2008. Analisis Gender dan Transformasi Sosial. Yogyakarta: Insist Press.

Khomsiyah. dan Indiantoro, Nur. 1998. Pengaruh Orientasi Etika Terhadap Komitmen dan Sensitivitas Etika Auditor Pemerintah di DKI Jakarta. Jurnal Riset Akuntansi Indonesia, 1 (1): 13-28.

Ludigdo, Unti. dan Machfoedz, Mas'ud. 1999. Persepsi Akuntan dan Mahasiswa tentang Etika Bisnis. Jurnal Riset Akuntansi Indonesia, 2 (1): 1-19.

Martadi, Indiana Farid. dan Suratna, Sri. 2006. Persepsi Akuntan, Mahasiswa Akuntansi, dan Karyawan bagian akuntansi dipandang dari segi gender terhadap etika bisnis dan etika profesi (Studi di wilayah Surakarta). Simposium Nasional Akuntansi IX Agustus.

Priyatno, Dwi. 2008. Mandiri Belajar SPSS (untuk Analisis Data \& Uji Statistik). Yogyakarta: Media Kom.

Rianto, Arvita. 2008. Analisis Sensitivitas Etis Mahasiswa Akuntansi Universitas Islam Indonesia Yogyakarta, Skripsi, Universitas Islam Indonesia, Yogyakarta.

Rustiana. 2003. Studi Empiris Novice Accountant: Tinjauan Gender. Jurnal Studi Bisnis. $1(2): 107-123$

Sekaran, Uma. 2003. Research Methods for Business: Metodologi untuk Penelitian Bisnis, edisi empat. Jakarta: Salemba Empat.

Sugiyono. 2005. Metode Penelitian Bisnis. Bandung: CV. Alfabeta.

Sugiyono. 2008. Statistika untuk Penelitian. Bandung: Alfabeta.

Yulianti dan Fitriany. 2005. Persepsi Mahasiswa Akuntansi Terhadap Etika Penyusunan Laporan Keuangan. Simposium Nasional Akuntansi VIII September. Hal 791-807. 